\title{
Collective Bargaining among Academic Librarians: A Survey of ACRL Members
}

\begin{abstract}
This study presents the results of a 1981 survey of ACRL personal members in the United States. Through a stratified random-sample model, nationwide and regional levels of collective bargaining activity among academic librarians were determined. As part of the survey, the attitudes of those working under a collective bargaining agreement were compiled. It was found that personal goals benefited the most, while organizational goals benefited the least from collective bargaining. In addition, various factors were analyzed to determine their impact on attitudinal responses. The general result was that the collective bargaining responses demonstrated a remarkable degree of homogeneity.
\end{abstract}

I RECENT YEARS collective bargaining has been an issue of much concern among academic librarians. Although the literature is generous in the areas of local or regional studies of collective bargaining ${ }^{1}$ and in the philosophical underpinnings of library union activities, ${ }^{2}$ there has been no statistically viable nationwide study of collective bargaining for college and university librarians.

The purpose of this article is to determine: (1) to what extent collective bargaining is occurring among academic librarians; (2) the attitude of those librarians involved in collective bargaining toward unionism at their institutions; and (3) the effect of different variables on the respondents.

During the months of February and March 1981, a stratified random sample of personal members in the United States, of the Association of College and Research Libraries (ACRL), was conducted. A survey was mailed to 700 of the members, to which 60.4 percent (423) responded. Stratified by regions of the United States, this return size not only validated the survey but could be inter-

Bob Carmack is dean of library services, I.D. Weeks Library, University of South Dakota at Vermillion; and John N. Olsgaard, former documents librarians and archivist, I.D. Weeks Library, is a doctoral student, Graduate School of Library and Information Science, University of Illinois at Urbana-Champaign. pretive of academic librarians' interest in the topic. The regional breakdown was constructed using models from previous research. Regions are: Northeast: Connecticut, Delaware, District of Columbia, Maine, Maryland, Massachusetts, New Hampshire, New Jersey, New York, Pennsylvania, Rhode Island, Vermont; Southeast: Alabama, Florida, Georgia, Kentucky, North Carolina, South Carolina, Tennessee, Virginia, West Virginia; Midwest: Illinois, Indiana, Iowa, Kansas, Michigan, Minnesota, Missouri, Nebraska, North Dakota, Ohio, South Dakota, Wisconsin; Southwest: Arizona, Arkansas, Louisiana, Mississippi, New Mexico, Oklahoma, Texas; West: Alaska, California, Colorado, Hawaii, Idaho, Montana, Nevada, Oregon, Utah, Washington, Wyoming.

In order to ensure a valid statistical analysis of that portion of the ACRL membership which is comprised of college or university librarians, a proportional allocation model was utilized to determine the sample size. The formula used for this purpose is shown in appendix A. The survey instrument itself is reproduced in appendix $B .^{3}$

The degree of collective bargaining occurring among academic librarians is shown in table 1 . The data indicate that approximately one-fourth of all college and university librarians are involved in collective bargaining activities. Somewhat surprising is the large 
TABLE 1

Extent of Collective Bargaining by Region

\begin{tabular}{|c|c|c|c|}
\hline Region & $\begin{array}{c}\text { Number of } \\
\text { Academic } \\
\text { Librarians } \\
N=\end{array}$ & $\begin{array}{c}\text { Number of } \\
\text { Collective } \\
\text { Bargaining } \\
\text { Responses } \\
N=\end{array}$ & $\%$ \\
\hline Northeast & 98 & 46 & 46.94 \\
\hline Southeast & 45 & - & - \\
\hline Midwest & 82 & 18 & 21.95 \\
\hline Southwest & 24 & - & - \\
\hline West & 49 & 8 & 16.33 \\
\hline Total & 298 & 72 & 24.16 \\
\hline $\begin{array}{l}\text { chi-square = } \\
\text { D.F. }=4\end{array}$ & $\begin{array}{l}H_{0}: 1 \\
H_{0}: \mid\end{array}$ & $\begin{array}{l}0.05 \mid=9 . \\
0.01 \mid=13\end{array}$ & \\
\hline
\end{tabular}

difference in the regional levels of collective bargaining. These levels ranged from almost half of the academic librarians in the Northeast participating in collective bargaining activities (46.94 percent), to values in the Southeast and Southwest so minimal that significant description is precluded. The chisquare test demonstrates that the results are statistically significant at both the .05 and .01 levels, and were not due to chance distribution.

The data also revealed that of those under some form of collective bargaining, 87.5 percent were under the same contract, as were other faculty members on their campus. Conversely, 12.5 percent were represented by their own individual union.

The responses to the third part of the questionnaire, "Section III: Attitudes toward Collective Bargaining," are given in table 2. It is almost axiomatic that individuals join unions to further personal rather than organizational needs, and the results of our survey tend to bear this out. It is not surprising that the questions that received the highest levels in the category "Change for the Better" were, in descending order:

Question 21: Due process (right to appeal alleged unfair practices)

Question 16: Salaries

Question 18: Fringe benefits

Conversely, the questions that received the highest percentage in the category "Change for the Worse" (even though the percentages were not phenomenal) were:

Question 1: Relationship with library administration

Question 2: Relationship with campus administration

Question 6: Quality of library services
These results were somewhat predicted in the literature prior to this survey. Dennis Chamot pointed out that: "Employees, while interested in the health and welfare of the organization, are more immediately concerned with income, working conditions, career development, and job security." 4 Further, it should be noted that the questions with the highest percentage of "Change for the Worse" highlight the fact that collective bargaining tends to bring out or emphasize the adversary relationship between library administrators and library union members; indeed, collective bargaining may become a source of conflict in and of itself. ${ }^{\mathrm{s}}$

Generally, the attitude of respondents to the questions in this survey could be stated this way: collective bargaining had either no impact or had bettered the conditions of academic librarians on the campuses where it occurred. Naturally, there was a good deal of difference among individual respondents on the effect of union activity at their particular institution. This variance was reflected in some of the comments requested and received at the end of the survey. Comments varied from one librarian from the Northeast who wrote, "I feel definitely that the presence of a collective bargaining agent with an active concern for librarians is beneficial," to a librarian from the Midwest who said, "Collective bargaining probably is the worst thing that ever happened to this university." Of course, there were also those who felt, like one, that "changes have been all but imperceptible."

The structure of the survey allowed a breakdown of the responses to collective bargaining as measured against several factors. This analysis was carried out on the following variables: sex, the type of academic library, the amount of supervisory duties, and the amount of professional experience that applied to the individual respondent. Generally, in the case of all variables tested, the respondents were remarkably homogeneous. It should be noted that the cases delineated below represent the exceptional rather than the commonplace occurrence. These particular cases all show a statistically significant level of difference as measured by a chisquare test at the .05 level.

As measured by the sex of the respondent, responses to three of the questions showed a 
TABLE 2

Overall Responses to Collective Bargaining in Percent $(N=72)$

\begin{tabular}{crrrr}
\hline \hline Question & $\begin{array}{c}\text { Change } \\
\text { forthe } \\
\text { Better }\end{array}$ & $\begin{array}{c}\text { Change } \\
\text { for the } \\
\text { Worse }\end{array}$ & $\begin{array}{c}\text { No } \\
\text { Change }\end{array}$ & $\begin{array}{c}\text { No } \\
\text { Response }\end{array}$ \\
\hline 1 & 20.83 & 13.89 & 54.17 & 11.11 \\
2 & 31.94 & 13.89 & 48.61 & 5.56 \\
3 & 44.44 & 1.39 & 47.22 & 6.94 \\
4 & 8.33 & 1.39 & 86.11 & 4.17 \\
5 & 4.17 & 2.78 & 88.89 & 4.17 \\
6 & 15.28 & 11.11 & 69.44 & 4.17 \\
7 & 12.50 & 6.94 & 76.39 & 6.94 \\
8 & 11.11 & 8.33 & 73.61 & 8.33 \\
9 & 20.83 & 5.56 & 65.28 & 6.94 \\
10 & 11.11 & 5.56 & 76.39 & 6.94 \\
11 & 22.22 & 6.94 & 63.89 & 6.94 \\
12 & 16.67 & 8.33 & 68.06 & 5.56 \\
13 & 34.72 & 6.94 & 52.78 & 5.56 \\
14 & 31.94 & 6.94 & 55.56 & 6.94 \\
15 & 23.61 & 6.94 & 62.50 & 5.56 \\
16 & 62.50 & 4.17 & 27.78 & 8.33 \\
17 & 40.28 & 2.78 & 48.61 & 5.56 \\
18 & 54.17 & 1.39 & 38.89 & 4.56 \\
19 & 44.44 & - & 50.00 & 4.17 \\
20 & 30.56 & 9.72 & 55.56 & 4.17 \\
21 & 70.83 & 1.39 & 23.61 & 4.17 \\
22 & 26.39 & 1.39 & 68.06 & 6.94 \\
23 & 20.83 & - & 75.00 & 55.56 \\
24 & 37.50 & - & & \\
\hline
\end{tabular}

significant degree of variation. They were:

Q8: Budget allocations

chi-square $=11.018$

Q9: Personnel allocations

Q18: Fringe benefits

chi-square $=6.516$

chi-square $=9.429$

$H_{O}:|P| \geqslant\left|P_{O} .05\right|=\quad$ D.F. $=2$

5.991

In the cases of both budget and personnel allocations, more male respondents tended to feel that there had been change for the better, while inversely, more female respondents believed things had changed for the worse. In the instance of fringe benefits, more females than males tended to believe collective bargaining had caused a change for the better.

Measuring the impact of collective bargaining on professional autonomy by both types of academic libraries and by years of experience yielded interesting data. The only question that resulted in any significant variation between expected values for university librarians and those for college librarians was Q15: Professional automony (chi-square = $6.819, .05=5.991$ ). University librarians tended to think that there had been a much larger degree of change for the worse than college librarians.

The analysis of experience sought to determine if there was a difference between the responses of those librarians with one to fifteen years of professional experience and those with sixteen or more years of experience. Again, the only question that demonstrated a significant difference was Q15 (chisquare $=6.999, .05=5.991)$. More of the younger group of librarians tended to believe there had been a change for the better than did the older group.

The last variable tested was to determine if there was a significant difference between those librarians who did not supervise other professional librarians and those who supervised one or more professional librarians (groups roughly equivalent in size). None of the questions showed a significant variation between these two groups.

On the basis of this national survey of ACRL members, various quantitative conclusions can be drawn. The first of these determinations would be that collective bargaining affects about 25 percent of all college and university librarians in the United States, and that the level of unionization fluctuates greatly depending on the region of the country. The second conclusion was that the majority of those working under collective bargaining contracts were either neutral or positively inclined toward the effects of un- 
ionization. It was also shown that the categories that improved the most, according to the respondents, were those of individual benefit to the members (e.g., salaries), whereas the areas that had shown the highest change for the worse were generally of an organizational nature (e.g., library services). The final determination that can be made of this study is that, for the most part, factors such as sex, type of library, supervisory duties, or years of professional experience did not make a significant difference in the responses. No one group benefited more than another from collective bargaining; specific exceptions to this generalization were delineated.

It must be stated that many of the respondents to the survey commented that although they they were not presently under any form of collective bargaining, their campuses were in some stage of beginning faculty unionization. Hence, it would behoove the profession to repeat this or a similar study periodically in order to gauge the growth or decline of collective bargaining within the profession.

It was not the purpose of this study to formulate or even attempt to explain the causal rationale of the various data configurations. Whether unionization is good, bad, or indifferent for the profession or its individual members remains a question for others to ponder. This study is merely a step along the path to that collective decision.

\section{REFERENCES}

1. For examples see Lothar Spong, "Collective Bargaining and University Librarians: Wayne State University," College \& Research Libraries 36:106-14 (March 1975); Mary Anne Burns and Jeanette Carter, "Collective Bargaining Faculty Status for Librarians: West Chester State College," College \& Research Libraries 36:115-20 (March 1975), or Theodore L. Guyton, Unionization: The Viewpoint of Librarians (Chicago: American Library Assn., 1975).

2. For examples see Gail Ann Schlachter, "Professionalism v. Unionism," Library Trends 25:451-73 (Oct. 1976); or Anne Commerton, "Union or Professional Organization? A Librarians's Dilemma," College \& Research Libraries 36:129-35 (March 1975).
3. Many of the attitudinal questions on the survey instrument were used with permission from Jean R. Kennelly, "The Current Status of Academic Librarians' Involvement in Collective Bargaining: A Survey," in Millicent D. Abell, ed., Collective Bargaining in Higher Education (Chicago: American Library Assn., 1976), p. 89-90.

4. Dennis Chamot, "The Effect of Collective Bargaining on the Employee-Management Relationship," Library Trends 25:491 (Oct. 1976).

5. See Marilyn A. Oberg, Mary Blackburn, and Joan Dible, "Unionization: Costs and Benefits to the Individual and the Library," Library Trends 25:443 (Oct. 1976).

Appendix A

$$
n=\frac{\sum_{i=1}^{5} \frac{N_{i}^{2} p_{i} q_{i}}{w_{i}}}{N^{2} D+\sum_{i=1}^{5} N_{i} p_{i} q_{i}}
$$

where $D=\frac{B^{2}}{4}$

$n$ = overall sample size

$N=$ population size

$N_{i}=$ strata size in the $i$ th region

$p_{i}=$ strata proportion that are college or university librarians in the $i$ th region

$q_{i}=1-p_{i}$

$w_{i}=$ weight factor; percentage of the population given by the ith region

$B=$ bound on the error of estimation; in this case .05 
Since, at the time of the sample, the actual proportion of ACRL members that were college or university librarians was not known, the most conservative estimate was used (i.e., $p_{i}$ and $q_{i}=.5$ ) to calculate the required number of responses. ACRL members were assigned individual and regional sequential identification numbers, and were selected on the basis of random-number generation.

Data Configuration

\begin{tabular}{lccccc}
\hline \hline Region & $\begin{array}{c}\text { Population } \\
\text { Size }\end{array}$ & $\begin{array}{c}\text { Number } \\
\text { Mailed }\end{array}$ & $\begin{array}{c}\text { Number } \\
\text { Required } \\
\text { Returns }\end{array}$ & $\begin{array}{c}\text { Actual } \\
\text { Returns }\end{array}$ & $w_{i}$ \\
\hline NE & 2,540 & 272 & 133 & 146 & .3497 \\
SE & 970 & 80 & 51 & 53 & .1335 \\
MI & 2,061 & 199 & 108 & 122 & .2837 \\
SW & 579 & 51 & 31 & 32 & .0797 \\
WE & 1,114 & 98 & 59 & 70 & .1534 \\
Total & 7,264 & 700 & 382 & 423 & 1.0000 \\
\hline
\end{tabular}

APPEndix B: SuRveY

\section{SECTION I: BACKGROUND}

1. Please check the appropriate box. Are you a:

Two year college librarian

Four year college librarian

University librarian

Public librarian

Other (please specify)
Special librarian

Library school student

Library school faculty

Retired librarian

2. Are you: Female Male

If you are not a college or university librarian you need not go further; please return this survey in the enclosed envelope.

3. Please check all appropriate box(es) of educational degrees obtained:

B.A. or B.S.

Masters (library science)

Masters (nonlibrary science)

Ed.D.

J.D.

Other (please specify)

4. How many years have you been a professional librarian?
Specialist degree (library science)

Specialist degree (nonlibrary science)

Ph.D. (library science)

Ph.D. (nonlibrary science)

5. How many professional positions have you held?

6. How many years have you been at your present location?

7. Do you have "faculty rank" (defined as having the privileges of faculty, but without the the ability for tenure) at your present location? yes no

8. Do you have "faculty status" (defined as having the privileges of faculty, including tenure) at your present location? yes no

9. Do you supervise other professional librarians at your present location? If yes, How many professional librarians do you supervise?

\section{SECTION II: COLLECTIVE BARGAINING}

1. Is it true that faculty collective bargaining is a fact on your campus?

2. Are librarians included in the faculty bargaining unit(s)? yes no yes no

3. If librarians are not included in the faculty bargaining unit(s), are librarians represented by other bargaining units? yes no

4. If librarians are represented for collective bargaining purposes, are library administrators represented by the same bargaining units? yes no

\section{SECTION III: ATTITUDES TOWARD COLLECTIVE BARGAINING}

With regard to the effects of collective bargaining on the status of academic librarians on your campus, please mark the below categories with the following numerals:

Change for the better $=1$

Change for the worse $=2$

No change $=3$ 
1. Relationship with library administration

2. Relationship with campus administration

3. Relationship with the faculty

4. Relationship with the students

5. Relationship with the public

6. Quality of library services

7. Quality of library collections

8. Budget allocations

9. Personnel allocations

10. Selection of clericals and paraprofessionals

11. Selection of librarians

12. Selection of library administrators

13. Participation in policy determination

14. Participation in decision making in general

15. Professional autonomy

16. Salaries

17. Tenure

18. Fringe benefits

19. Leaves and vacations

20. Promotion

21. Due process (right to appeal alleged unfair practices)

22. Work schedules

23. Length of workday

24. Number of days in work year

Please feel free to include any comments you may have to any of the above categories in the following space and * the item indicated.

Comments:

Thank you for filling out this survey. Please return in the enclosed self-addressed, stamped envelope. 


\title{
From JAI PRESS INC.
}

\author{
Volume 17 of
}

Foundations in

Library and Information Sciences

A Series of Monographs, Texts, and Treatises

Series Editor: Robert D. Stueart
Graduate School of Library and Information Science

Simmons Gollege - Boston

"Librarians and library school faculty members are becoming accustomed to finding the volumes of this series among the most useful studies of their subjects. - JOURNAL OF ACADEMIC LIBRARIANSHIP

\section{Available June 1982}

\section{Options For The 80s:}

Proceedings of the Second National Conference of the Association of College and Research Libraries

Edited by Michael D. Kathman, College of St. Benedict and St. John s University and Virgil F. Massman, James J. Hill. Reference Library
ISBN 0-89232-276-4
Cloth
2 Volumes
Approx. $\$ 75.00$
Ca. $800 \mathrm{pp}$.

The Second National Conference of the Association for College and Research Libraries has taken as its focus an assessment of the options that lie before us in the next decade.

This volume will contain 56 papers present on a variety of topics. They will include: Information Services and Bibliographic instruction: Special Collections and Facilities. Performance Evaluation and Governance: Networking. Cooperation and Technology: Standard and Collection Development: Administration and Funding:' The Role of the Library and the Librarian in Academic Institutions: and Planning and Bibliographic Control.

In addition. invited papers on major issues as well as the text of the five theme addresses will be presented in an attempt to identify the major oportunities and challenges that confront higher education and academic and research libraries during the $1980 \mathrm{~s}$

Please write us for a complete catalog.

University libraries depend upon their faculty for recommendations before purchasing. Please encourage your library to subscribe to this series.

INSTITUTIONAL STANDING ORDERS will be granted a

$10 \%$ discount and be filled automatically upon publication

Please indicate initial volume of standing order
INDIVIDUAL ORDERS must be prepaid by personal check or credit card Please include $\$ 200$ per volume for postage and handling on all domestic orders. $\$ 300$ for foreign 


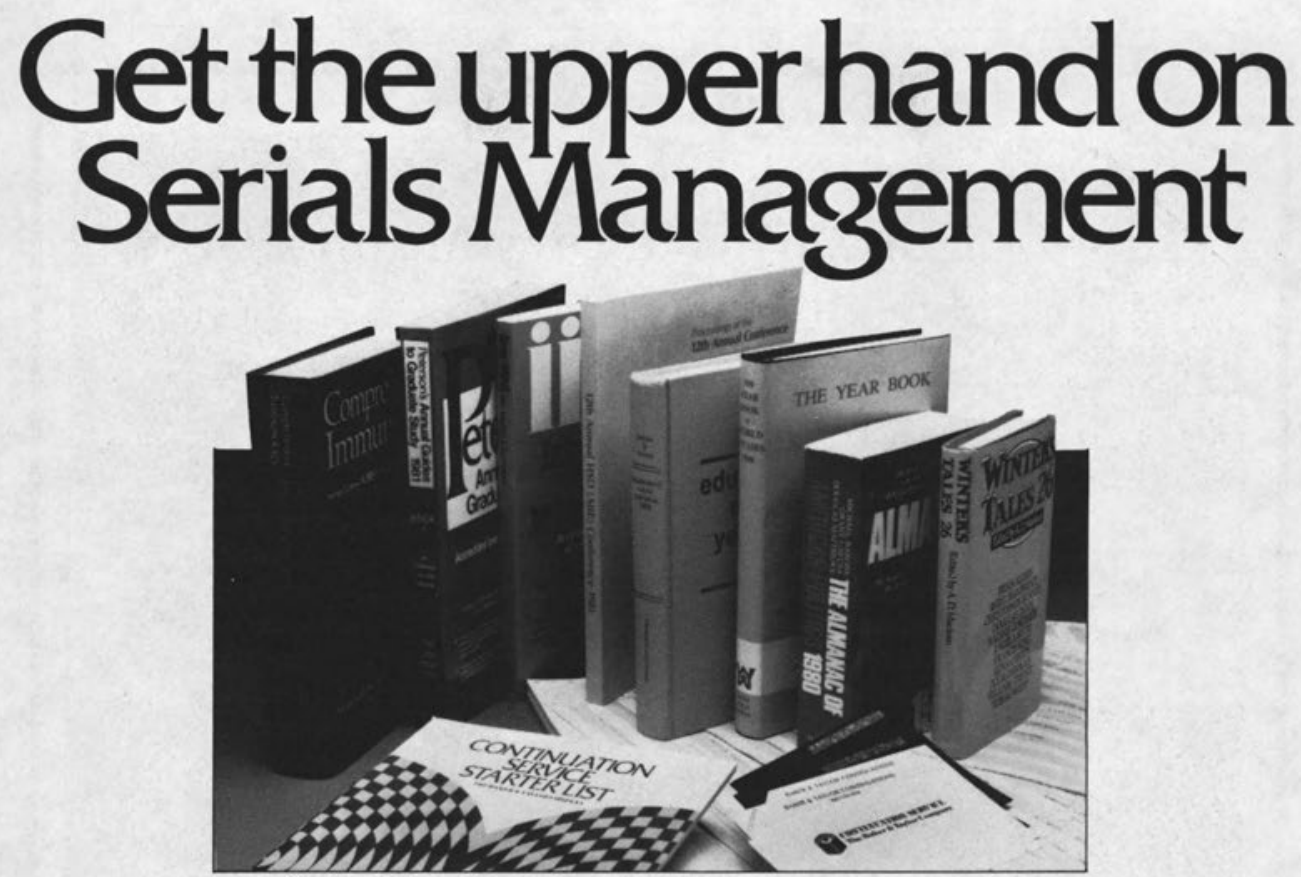

The right tools are needed to manage an outstanding serials collection. Hard work and dedication alone are not enough to assure professional serials management. Baker \& Taylor's Continuation Service provides the collection development tools and management reports you need to do the job.

\section{Collection Development Tools}

Starter List. Includes 1,300 of the most frequently demanded serials; each entry contains full selection and ordering data as extracted from the Continuation Service database.

Subject Bibliography. Indicates title availability by discipline in order to facilitate the establishment, expansion, and enrichment of a serials collection.

Expanded Starter List (Microfiche). Provides access to the bibliographic records of over 7,000 titles of prime interest to academic and research libraries.

\section{$\square$ Management Reports}

Customer Profile. Confirms titles on standing order with Baker \&
Taylor; supplied upon opening an account and at any time upon request.

Shipment History. Supplies data on issues of standing orders which have been shipped to the user; information is cumulated weekly and reports are available quarterly, semiannually, or annually upon request

Status Report. Provides information on issues of titles currently on order and is available quarterly, semiannually, or annually upon request.

Individual Title Report. Alerts Continuation Service users to such information as title changes, out-of-print data, discontinued titles, and delays in publication.

Alternate Year Capability. Allows purchase flexibility when budgets are a factor.

With an experienced staff of serials librarians always available to answer questions, Baker \& Taylor ensures a comprehensive selection and prompt fulfillment of stand- ing orders. For further information. please write or call the Sales Department of the Baker \& Taylor distribution center nearest you.



\section{Baker \& Taylor}

Book Professionals Since 1828

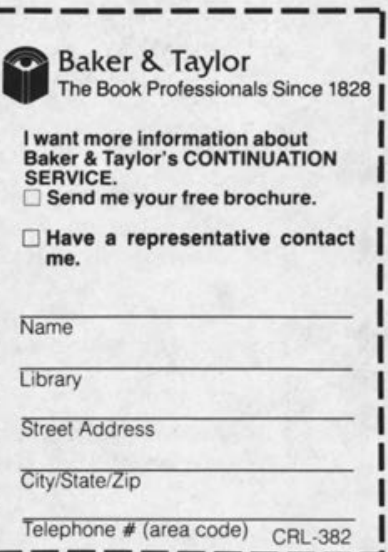

\section{Eastern Division}

50 Kirby Avenue

Somerville. New Jersey 08876

(201) $722-8000$

\section{Midwestern Division}

Gladiola Avenue

Momence, Illinois 60954

(815) $472-2444$
Southern Division

Mt. Olive Road

Commerce, Georgia 30599

(404) $335-5000$
Western Division

380 Edison Way

Reno. Nevada 89564

(702) $786-6700$ 


\title{
"...a splendid achievement." LIBRARY JOURNAL.
}

\section{Index of English Literary Manuscripts}

\author{
Volume I, 1450-1625, Parts 1 and 2 \\ Compiled by Peter Beal \\ 2 vols. 1,258 pp. total. 1980. illus. (0-7201-0807-1). \$320. \\ Volume IV, 1800-1900, Part 1, A-G \\ Compiled by Barbara Rosenbaum and Pamela White \\ 900 pp. Jan. 1982. illus. (0-7201-1587-6). about $\$ 160$.
}

Index of English Literary Manuscripts is a major reference work that lists, describes and locates literary texts from $1450-1900$. It is an invaluable source for locating the works of 270 major British and Irish authors, including some previously unrecorded discoveries. Planned for five volumes, the Index brings together references to manuscripts, corrected proofs and contemporary transcripts held in hundreds of public and private collections the world over. It also contains reproductions of selected works.

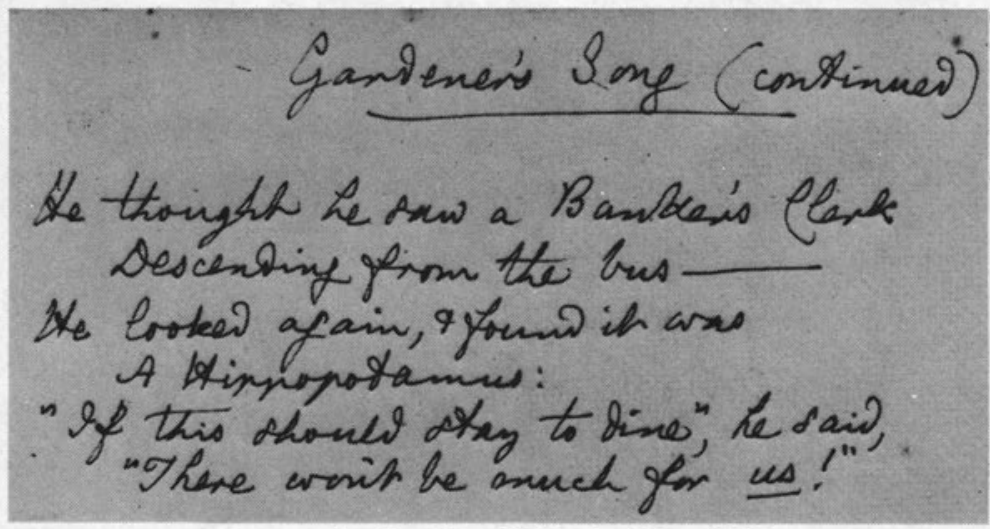

An excerpt from Lewis Carroll's "Gardener's Song," 1887.

Each volume has an alphabetical listing of authors followed by six categories for manuscript entries. Both listings provide a basis for research to professors, biographers, historians and anyone who needs clear, concise information on English Literature.

Volume I, Parts 1 and 2, details approximately 12,000 manuscripts from the works of 72 Renaissance writers including previously unknown works by Francis Bacon and Edmund Spenser.

Volume IV, Part 1, includes the extant works of 23 nineteenth-century authors and records unpublished poems by Elizabeth Barrett Browning, Samuel Taylor Coleridge and others.

For more information on these and other Mansell publications, please write to: 